\title{
Efficacy of sofosbuvir in the treatment-naïve patients infected with 3a genotype of Hepatitis C.
}

1. MBBS

Post Graduate Resident

Punjab Institute of Cardiology, Lahore.

2. MBBS, FCPS

Assistant Professor Pathology

KEMU, Lahore.

3. M.S (Chemistry)

University of Management and Technology, Lahore.

4. MBBS, FCPS

Assistant Professor Accident and Emergency Department

KEMU, Mayo Hospital, Lahore.

5. MBBS, FCPS

Associate Professor Internal

Medicine

KEMU, Lahore.

6. MBBS

Medical Officer Neurology

Sheikh Zayed Hospital, Lahore.

7. MBBS, FCPS

Assistant Professor Community

Medicine

KEMU, Lahore.

\section{Correspondence Address:}

Dr. Sarmad Zahoor

Momina Abad B, Street No. 1,

Nowshera Road, Gujranwala.

drsarmadzahoor@gmail.com

Article received on:

04/03/2020

Accepted for publication:

22/06/2020

\section{INTRODUCTION}

Hepatitis $C$ is a viral infection caused by a virus known as hepatitis $C$ virus. Hepatitis $C$, mainly the infection of liver, causes hepatocellular carcinoma, cirrhosis and fibrosis. This liver affecting disease has infected 185 million people worldwide. ${ }^{1}$ It may be acute or chronic. However, 15-45\% cases resolve spontaneously within 6 months. ${ }^{2}$ Hepatitis $\mathrm{C}$ virus, an enveloped, single-stranded RNA virus belonging to family Flaviviridae, genus Hepacivirus and species Hepatitis C virus, has six genotypes with $3 a$ being the most common in Pakistan. ${ }^{3,4}$ Six genotypes of HCV are further subdivided into 80 sub-types. The rate of mutation in nucleotides is $1-5 \%$. The rate of mutation in genotypes is $30-50 \%$ and in subtypes is $15-30$ $\%{ }^{5}$ The reasons behind mutation are lack of proofreading and rapid rate of replication. ${ }^{6}$

Hepatitis $\mathrm{C}$ is a blood borne disease and is transmitted through body fluids, sexual intercourse, blood transfusions without screening, use of already used syringes and mother to child during pregnancy. Barbershops, homosexuality, surgical instruments, tattooing and dialysis all are contributing to spread of HCV. ${ }^{7}$

Genome of $\mathrm{HCV}$ is a positive sense strand with highly conserved un-translated region (UTR) for initiation and an open reading frame (ORF) for coding structural and nonstructural proteins former being core proteins $\mathrm{E} 1$ and $\mathrm{E} 2$, and latter being NS1, NS2,NS3, NS4A, NS4B, NS5A and NS5B. ${ }^{8-10}$ Structural proteins mainly have their 
role in entry and release of virus. ${ }^{11}$ Non-structural proteins play their role in replication- with NS3 unwinding RNA, NS4 forming membranous web with ER, NS5 (NS5A + NS5B) having role in replication and completion of replication being performed by NS2. ${ }^{12-14}$ NS5B, also known as RNA dependent RNA polymerase, adds new RNA genome. Recent research shows development of NS5B inhibitor which inhibits viral replication. ${ }^{15}$

First effort towards HCV treatment was acyclovir but it was unable to show a satisfactory response. ${ }^{16}$ Positive response by INF-alfa (a cytokine that directly stops viral replication along with production of antiviral proteins for killing virus) was encouraged for further study and was found to have SVR of $6 \%$ after 24 weeks of therapy which increased by increasing duration to 48 weeks. ${ }^{17-19}$ Positive response of ribavirin against RNA and DNA viruses in animals was also observed in 1972 and approved by WHO in $1972 . .^{20,21}$ Ribavirin has a ribose sugar in its structure. So, its $\mathrm{OH}$ group at carbon 2 makes interaction with RNA metabolism possible. Similarity of nucleosides of ribavirin with viral genome causes mutagenesis. ${ }^{22,23}$ In addition, it inhibits replication and shows immunosuppressive response as well by transferring T-helper 2 (Th2) cells to Th1 cells. ${ }^{24,25}$ Ribavirin was used as monotherapy and decreased ALT levels but did not affect viral RNA levels. ${ }^{26}$ Then, ribavirin was used in combination with INF-alfa for 24 weeks in another trial. SVR became $24 \%$ and increased twice as therapy duration doubled. ${ }^{27}$ In 1998 FDA approved standard therapy for HCV patients of genotype 2-6 (that includes $3 a$ as well) to be INF-alfa and Ribavirin for 24 weeks. ${ }^{28}$

The time duration for this therapy was long and was also hard to be tolerated by patients. Consequently, scientists tried to decrease the number of doses by increasing half-life of INF by pegylation (Combination of INF with inert compound that is polyethylene glycol). Pegylated interferon (PEG-INF) showed a high SVR of 39\%. When PEG-INF was coupled with RBV, SVR came out to be $54 \%$ to $56 \%$ with the therapy duration being 48 weeks. ${ }^{29}$ FDA approved therapy dose and duration of PEG-INF and RBV according to genotype of HCV. For genotype 2 and 3 the therapy duration is 24 weeks and SVR is $95 \% .{ }^{30}$

In 2011, FDA approved oral therapy of direct acting antiviral (DAA) drugs which proved to be more effective, safer and well tolerated than older therapies. These included: HCV Protease Inhibitors (Simeprevir and Paritaprevir/Ritonavir), HCV NS5A Inhibitors (Daclatasvir, Ombitasvir, Ledipasvir) and HCV NS5B Polymerase inhibitor (Sofosbuvir). ${ }^{31,32}$

Sofosbuvir (SOF) is a uridine analogue and imitates like NS5B polymerase substrate, inhibits NS5B polymerase activity and thus arrests HCV RNA replication. ${ }^{33}$ In 2013, FDA approved a combination of Sofosbuvir and Ribavirin for genotype 3 for 24 weeks. ${ }^{34}$ Steinebrunner et al. investigated Sofosbuvir efficacy for all genotypes in combination with ribavirin and found SVR to be $92 \%$ for genotype 3 with therapy duration of 24 weeks. ${ }^{35}$ In another study SVR for genotype 3a was $89 \%$ in treatment-naïve, non-cirrhotic patients. ${ }^{36}$ VALENCE study of Europe proved SVR to be $85 \%$ for genotype 3 when Sofosbuvir was used with RBV. ${ }^{37}$ A study in Pakistan was conducted in Rawalpindi to determine the efficacy of SOF with RBV for genotype 3 and found that $96.5 \%$ of patients had negative PCR at the end of treatment. ${ }^{38}$ Data from all over the globe with more presentation from Europe is available which is more centered on genotype 1.39-41 However, there is a lack of data on its efficacy pertaining to genotype $3 .^{42}$ Here our study may help to provide a leading tool for the community to assess recovery of HCV patients. In this study viral response after completion of Sofosbuvir therapy was noted to evaluate the efficacy of the drug in treatment-naïve patients.

\section{AIMS AND OBJECTIVES}

1) Analyzing the efficacy of Sofosbuvir in HCV naive patients infected with 3 a genotype who have never had interferon treatment

2) To study different factors that affect the efficacy of Sofosbuvir 


\section{MATERIAL \& METHODS}

This experimental study was conducted at Mayo Hospital, Lahore, Punjab, Pakistan from August 2016 to September 2017.

The study protocol was approved by the institutional review board and was consistent with ethical standards and policies of the institution in accordance to the declaration of Helsinki. Informed consent was obtained from all the patients and all questions were answered. All the patients of age less than 75 infected with HCV genotype $3 a$ (confirmed by PCR) with no previous history of any treatment of Interferon or drugs pertaining to $\mathrm{HCV}$ treatment with no sign(s) of decompensated liver disease (melena, encephalopathy, hematemesis, jaundice, ascites) were enrolled. Only the Pakistani Nationals who were HIV negative and had never visited abroad were selected for study. Any patient with HCV genotype other than $3 \mathrm{a}$, or with any sign of decompensation, HIV-positive, or foreign national was excluded from study. Serum AST and ALT levels of the patients were measured using commercially made kits through spectrophotometer along with serum creatinine level based on Jaffe's method at the start of study. Real Time Quantitative PCR along with PCR genotyping was done at the start of treatment and a quantitative PCR was repeated after following patients for 24 weeks at the end of treatment to determine the response of therapy at the end (end of treatment response i.e ETR). Proper history to know source of spread of Hepatitis was taken that included history of blood transfusion, family history of HCV and history of IV drug abuse. Any co-morbid condition like diabetes or hypertension was also noted. All patients were treated with sofosbuvir $400 \mathrm{mg}$ once daily and Ribavirin 400mg thrice daily. Data was analyzed using SPSS 20.

\section{RESULTS}

In this study 262 patients infected with genotype 3a were enrolled in which 43 patients left and did not give follow up for following reasons: 26 patients had financial constraints barring them from following up, while 17 patients were noncompliant. 219 patients continued the therapy out of which 11 patients discontinued due to adverse events (due to preexisting comorbidities or otherwise); 208 patients completed the therapy i.e. 24 weeks.

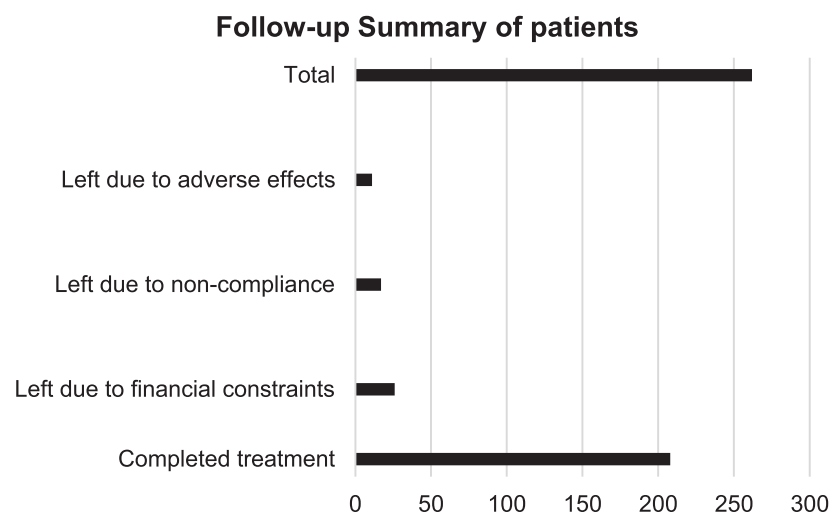

Out of 208 patients who completed the treatment, $201(96.6 \%)$ patients showed positive response (deciphered by satisfactory end of treatment response i.e ETR) out of which 79 (39.3\%) were male and $122(60.7 \%)$ were female. Two patients relapsed; one of them relapsed after 8 weeks and the other after 12 weeks. Five patients didn't respond to treatment.

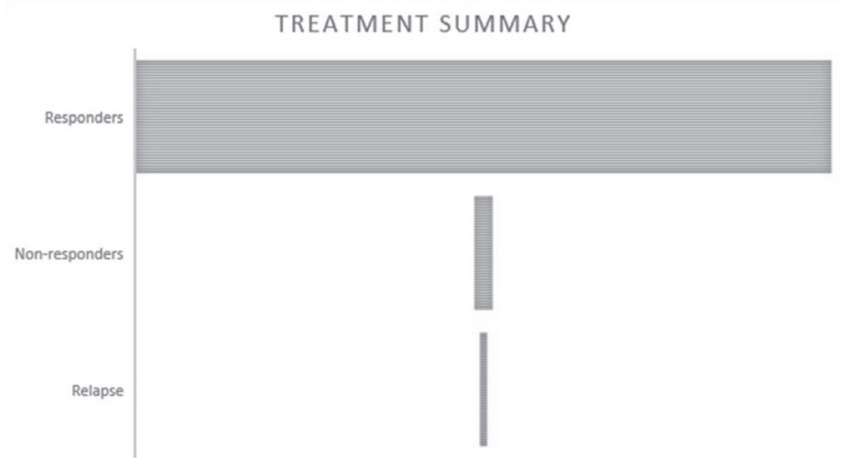

Mean patient age, ALT, AST, viral load and creatinine level were 42.47 ( \pm 11.38 years), 76.44 ( $\pm 45.51 \mathrm{IU} / \mathrm{I}), 71.71$ ( $\pm 45.26 \mathrm{IU} / \mathrm{I}), 1794133.24$ $( \pm 5110550.09 \mathrm{IU} / \mathrm{mL})$ and $0.8( \pm 0.2 \mathrm{~g} / \mathrm{dL})$ respectively. Considering $8 \times 10^{5} \mathrm{IU} / \mathrm{mlor}$ above as high viral load, 7 patients who left treatment had low viral load while 4 had high viral load. Among the responders 142 had low viral load while 59 had high viral load. 2 out of 5 non responders had high viral load and both the patients who relapsed had high viral load. 46 (21\%) patients had HCV positive partner in which $18(8.2 \%)$ were male and $28(12.8 \%)$ were female. $30(13.7 \%)$ patients were drug abusers and all were male. 65(29.7 
$\%$ patients had a history of blood transfusion in which $49(22.38 \%)$ were female and 16(7.32\%) were male.

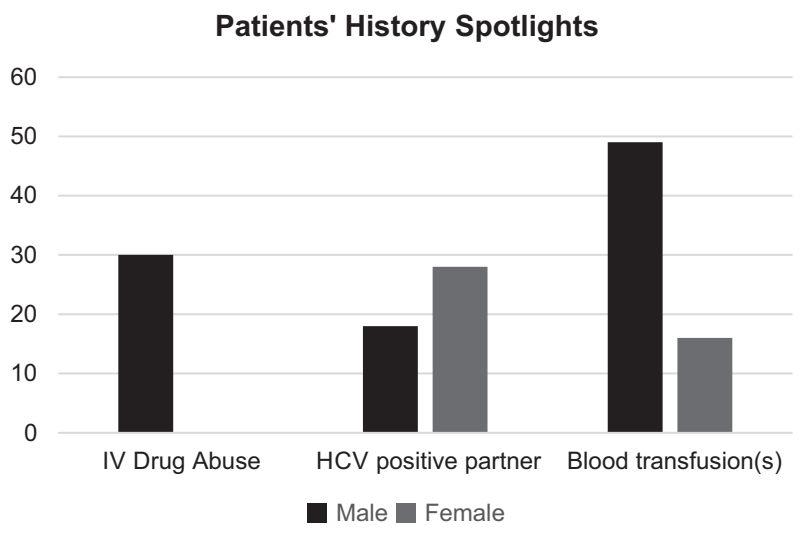

As mentioned above, 11 patients left the treatment due to preexisting comorbidities or otherwise, the breakdown is as follows: 8 patients discontinued the treatment due to fatigue, myalgia, marked pallor and weight loss. One patient left the therapy due to congestive heart failure. One known diabetic and hypertensive patient discontinued the treatment due to pedal edema and pallor. One diabetic patient left the treatment due to chronic kidney disease (CKD) and anemia.

\section{DISCUSSION}

$3 \%$ of world population is infected with HCV. HCV may be acute or chronic. Chronicity of HCV leads to DCLD and hepatocellular carcinoma. Rate of death due to HCV has increased. The misery associated with $\mathrm{HCV}$ infection was ameliorated by discovery of INF and RBV treatment. INF boosts immune response while ribavirin is an antiviral agent. The therapy duration for each genotype is different. Most common genotype in Pakistan is $3 a$ for which the recommended treatment was with INF-alpha and ribavirin for 24 weeks. Long therapy duration and adverse events made the people reluctant to initiate and continue therapy. Recently, new generation DAA drugs were developed that led to a new era towards treatment of Hepatitis $\mathrm{C}$. They were polymerase inhibitors in which SOF was one of them.

SOF is a nucleotide analogue (NS5B inhibitor) which was approved by FDA in $2013 .^{34}$ It is a very effective drug with less adverse effects.
Data on its efficacy was mainly centered around genotype 1 which was most prevalent in the West. However, data for genotype 3a was deficient and was need of the hour. There were very few trials explaining efficacy of SOF for genotype 3a which included FISSION, FUSION, POSITRON, ALLY-3 and BOSSON trials. All these were suggestive of good efficacy and better acceptance both in cirrhotic and non-cirrhotic patients in naïve as well as in INF-experienced patients. ${ }^{43-47}$ Valence trial showed an SVR of $93 \%$ in naïve patients of genotype 3a. SOF showed $96.5 \%$ efficacy against GT-3 in another trial at Rawalpindi. Another study of Pakistan RESiP trial involved $94 \%$ of patients infected with genotype $3 a$ proved to have an SVR of $97 \%$ in naïve patients. ${ }^{48}$

In our study, 262 patients were included of which 208 completed therapy (24 weeks). The response after therapy was $96.6 \%$. Results of previous studies were very close to it. There were 2 patients who showed relapse i.e. after completion of therapy and PCR being non-detectable, viral load became detectable on PCR again. This can be due to mutant variants or re-infection. 5 patients did not show the response against SOF. 3 patients were not taking there medications as prescribed while 2 patients didn't respond despite being compliant on completion of treatment.

11 patients discontinued therapy due to moderate to severe adverse events i.e. anemia, myalgia etc. Some of them left due to co-morbidities i.e. IHD, DM, and HTN. So, we conclude that side effects of the drugs accentuating the preexisting comorbidities are still the main problem encountered by the patients resulting in noncompliance coupled with their unawareness to severity of the disease. One of two diabetic patients left the treatment because they suffered from chronic kidney disease and weight loss. So, adverse events need to be managed properly in diabetics and in patients with other co-morbid conditions.

26 patients in our study discontinued the medication due to financial reasons and unable to afford the medication. It is an important consideration in a country like Pakistan where the 
model of payment is either government based or self-payment. Most of our patients belonged to poor socioeconomic status and were helped by Social welfare Department of the hospital but the funds are not consistent. This consideration should be kept in mind before starting treatment.

SOF in combination with other DAA also give very effective results. A recent study showed $90 \%$ efficacy of SOF plus Declatasvir for 12 weeks in naïve patients of $3 a$ and $86 \%$ in INF experienced patients of $3 a{ }^{45}$ The combination of other DAA with SOF was effective with usage for short duration but was expensive. Reducing its cost and increasing duration of SOF with other DAA may increase efficacy.

The use of SOF and other DAA and their therapy duration is not well known for HCV GT-3a patients. We tried to highlight these points in our study. Another issue is the HCV relapse after taking complete therapy of SOF plus RBV. We found only 2 cases in our study. Our study doesn't have a long-term follow up data to see any long term or rare side effects or the rate of relapse beyond our follow up points. In addition, we lost 43 patients to follow up due to various reasons that might have created unconscious selection bias. More work needs to be done to find the long term efficacy of novel antiviral agents.

\section{CONCLUSION}

Patients with HCV genotype $3 a$ have shown promising improvement in treatment response with Sofosbuvir as compared to the older treatment regimes. In contrast to the long duration of treatment and more disabling adverse effects profile of conventional regimes, Sofosbuvir, with its greater therapeutic efficacy and relatively welltolerated adverse effects, is expected to provide a break-through in treating Hepatitis $\mathrm{C}$ and minimizing the incidence of its complications.

\section{Competing Interests}

The authors declare that they have no competing interests.

Copyright@ 22 June, 2020.

\section{REFERENCES}

1. Petruzziello A, Marigliano S, Loquercio G, Cozzolino A, Cacciapuoti C. Global epidemiology of hepatitis $C$ virus infection: An up-date of the distribution and circulation of hepatitis $\mathbf{C}$ virus genotypes. World journal of gastroenterology. 2016; 22(34):7824-40.

2. Lozano R, Naghavi M, Foreman K, Lim S, Shibuya K, Aboyans $\mathrm{V}$, et al. Global and regional mortality from 235 causes of death for 20 age groups in 1990 and 2010: A systematic analysis for the Global Burden of Disease Study 2010. Lancet (London, England). 2012; 380(9859):2095-128.

3. Simmonds P, Bukh J, Combet C, Deleage G, Enomoto $\mathrm{N}$, Feinstone $\mathrm{S}$, et al. Consensus proposals for a unified system of nomenclature of hepatitis $\mathbf{C}$ virus genotypes. Hepatology (Baltimore, Md). 2005; 42(4):962-73.

4. Simmonds P, Holmes EC, Cha TA, Chan SW, McOmish $\mathrm{F}$, Irvine $\mathrm{B}$, et al. Classification of hepatitis $\mathbf{C}$ virus into six major genotypes and a series of subtypes by phylogenetic analysis of the NS-5 region. The Journal of general virology. 1993; 74 ( Pt 11):2391-9.

5. Bukh J, Purcell $\mathrm{RH}$, Miller $\mathrm{RH}$. Sequence analysis of the core gene of 14 hepatitis $C$ virus genotypes. Proceedings of the National Academy of Sciences of the United States of America. 1994; 91(17):8239-43.

6. Echeverria N, Moratorio G, Cristina J, Moreno P. Hepatitis $\mathbf{C}$ virus genetic variability and evolution. World journal of hepatology. 2015; 7(6):831-45.

7. Afzal MS, Shah ZH, Ahmed H. Recent HCV genotype changing pattern in the Khyber Pakhtunkhwa province of Pakistan; is it pointing out a forthcoming problem? The Brazilian Journal of Infectious Diseases. 2016; 20(3):312-3.

8. Hijikata M, Mizushima H, Akagi T, Mori S, Kakiuchi N, Kato $\mathrm{N}$, et al. Two distinct proteinase activities required for the processing of a putative nonstructural precursor protein of hepatitis C virus. Journal of virology. 1993; $67(8): 4665-75$.

9. Penin F, Dubuisson J, Rey FA, Moradpour D, Pawlotsky JM. Structural biology of hepatitis $\mathbf{C}$ virus. Hepatology (Baltimore, Md). 2004; 39(1):5-19.

10. Lindenbach BD, Rice, C. M. Flaviviridae: The viruses and their replication. Fields Virology. Philadelphia: Lippincott Williams \& Wilkins; 2001. p. 991-1042.

11. Tellinghuisen TL, Rice CM. Interaction between hepatitis $\mathbf{C}$ virus proteins and host cell factors. Current opinion in microbiology. 2002; 5(4):419-27. 
12. Serebrov V, Pyle AM. Periodic cycles of RNA unwinding and pausing by hepatitis C virus NS3 helicase. Nature. 2004; 430(6998):476-80.

13. Egger D, Wolk B, Gosert R, Bianchi L, Blum HE, Moradpour D, et al. Expression of hepatitis C virus proteins induces distinct membrane alterations including a candidate viral replication complex. Journal of virology. 2002; 76(12):5974-84.

14. Khromykh AA, Westaway EG. Subgenomic replicons of the flavivirus Kunjin: Construction and applications. Journal of virology. 1997; 71(2):1497-505.

15. De Francesco $R$, Migliaccio $G$. Challenges and successes in developing new therapies for hepatitis C. Nature. 2005; 436(7053):953-60.

16. Pappas SC, Hoofnagle JH, Young N, Straus SE, Jones EA. Treatment of chronic non-A, non-B hepatitis with acyclovir: Pilot study. Journal of Medical Virology. 1985; 15(1):1-9.

17. Wohnsland A, Hofmann WP, Sarrazin C. Viral determinants of resistance to treatment in patients with hepatitis C. Clinical microbiology reviews. 2007; 20(1):23-38.

18. Feld $\mathrm{JJ}$, Hoofnagle $\mathrm{JH}$. Mechanism of action of interferon and ribavirin in treatment of hepatitis $\mathbf{C}$. Nature. 2005; 436(7053):967-72.

19. Davis GL, Balart LA, Schiff ER, Lindsay K, Bodenheimer $\mathrm{HC}$, Jr., Perrillo RP, et al. Treatment of chronic hepatitis C with recombinant interferon alfa. A multicenter randomized, controlled trial. The New England journal of medicine. 1989; 321(22):1501-6.

20. Sidwell RW, Huffman JH, Khare GP, Allen LB, Witkowski JT, Robins RK. Broad-spectrum antiviral activity of Virazole: 1-beta-D-ribofuranosyl-1,2,4-triazole3-carboxamide. Science (New York, NY). 1972; 177(4050):705-6.

21. Snell NJC. Ribavirin - current status of a broad spectrum antiviral agent. Expert Opinion on Pharmacotherapy. 2001; 2(8):1317-24.

22. Crotty S, Maag D, Arnold JJ, Zhong W, Lau JY, Hong $Z$, et al. The broad-spectrum antiviral ribonucleoside ribavirin is an RNA virus mutagen. Nature medicine. 2000; 6(12):1375-9.

23. Crotty $S$, Cameron CE, Andino R. RNA virus error catastrophe: Direct molecular test by using ribavirin. Proceedings of the National Academy of Sciences. 2001; 98(12):6895-900.
24. Leyssen P, Balzarini J, De Clercq E, Neyts J. The predominant mechanism by which ribavirin exerts its antiviral activity in vitro against flaviviruses and paramyxoviruses is mediated by inhibition of IMP dehydrogenase. Journal of virology. 2005;79(3):19437.

25. Hultgren C, Milich DR, Weiland O, Sallberg M. The antiviral compound ribavirin modulates the $T$ helper (Th) $1 /$ Th2 subset balance in hepatitis $B$ and $C$ virusspecific immune responses. The Journal of general virology. 1998; 79 ( Pt 10):2381-91.

26. Dusheiko G, Main J, Thomas H, Reichard O, Lee C, Dhillon A, et al. Ribavirin treatment for patients with chronic hepatitis C: Results of a placebo-controlled study. Journal of hepatology. 1996; 25(5):591-8.

27. Poynard T, Marcellin P, Lee SS, Niederau C, Minuk GS, Ideo G, et al. Randomised trial of interferon alpha2b plus ribavirin for $\mathbf{4 8}$ weeks or for 24 weeks versus interferon alpha2b plus placebo for 48 weeks for treatment of chronic infection with hepatitis C virus. International Hepatitis Interventional Therapy Group (IHIT). Lancet (London, England). 1998; 352(9138):1426-32.

28. Mangia A, Santoro R, Minerva N, Ricci GL, Carretta V, Persico $M$, et al. Peginterferon alfa-2b and ribavirin for $\mathbf{1 2}$ vs. 24 weeks in HCV genotype 2 or $\mathbf{3}$. The New England journal of medicine. 2005; 352(25):2609-17.

29. Reddy KR, Wright TL, Pockros PJ, Shiffman M, Everson $G$, Reindollar R, et al. Efficacy and safety of pegylated $(40 \square k d)$ interferon $\mathrm{a} \square 2 \mathrm{a}$ compared with interferon $\mathrm{a} \square 2 \mathrm{a}$ in noncirrhotic patients with chronic hepatitis C. Hepatology (Baltimore, Md). 2001; 33(2):433-8.

30. Strader DB, Wright T, Thomas DL, Seeff LB. Diagnosis, management, and treatment of hepatitis C. Hepatology (Baltimore, Md). 2004; 39(4):1147-71.

31. Jesudian AB, Gambarin-Gelwan M, Jacobson IM. Advances in the treatment of hepatitis $C$ virus infection. Gastroenterology \& hepatology. 2012; 8(2):91-101.

32. Stedman CA. Current prospects for interferonfree treatment of hepatitis $C$ in 2012. Journal of gastroenterology and hepatology. 2013; 28(1):38-45.

33. Yamashita T, Kaneko S, Shirota Y, Qin W, Nomura T, Kobayashi $\mathrm{K}$, et al. RNA-dependent RNA polymerase activity of the soluble recombinant hepatitis $C$ virus NS5B protein truncated at the $\mathrm{C}$-terminal region. The Journal of biological chemistry. 1998; 273(25):1547986. 
34. Food and drug administration. SOVALDI (sofosbuvir) tablets, for oral use. 2013 [Available from: http://www.accessdata.fda.gov/drugsatfda_docs/ label/2013/204671s000lbl.pdf.

35. Steinebrunner N, Sprinzl MF, Zimmermann T, Worns MA, Zimmerer T, Galle PR, et al. Early virological response may predict treatment response in sofosbuvir-based combination therapy of chronic hepatitis $\mathbf{c}$ in a multicenter "real-life" cohort. BMC gastroenterology. 2015; 15:97.

36. Feld JJ, Maan R, Zeuzem S, Kuo A, Nelson DR, Di Bisceglie $A M$, et al. Effectiveness and safety of sofosbuvir-based regimens for chronic hcv genotype 3 infection: Results of the HCV-TARGET Study. Clinical infectious diseases: An official publication of the Infectious Diseases Society of America. 2016; 63(6):776-83.

37. Zeuzem S, Dusheiko GM, Salupere R, Mangia A, Flisiak $\mathrm{R}, \mathrm{Hyland} \mathrm{RH}$, et al. Sofosbuvir and ribavirin in HCV genotypes 2 and 3. The New England journal of medicine. 2014; 370(21):1993-2001.

38. Akhter TS, Umar M, Khaar HT, Aslam F, Nisar G, Naseer A, et al. Sofosbuvir for the treatment of Hepatitis $\mathbf{C}$ Genotype 3 infected patients in Pakistan. Journal of Ayub Medical College, Abbottabad: JAMC. 2016; 28(4 Suppl 1):S884-s9.

39. Osinusi A, Meissner EG, Lee YJ, Bon D, Heytens L, Nelson $A$, et al. Sofosbuvir and ribavirin for hepatitis C genotype 1 in patients with unfavorable treatment characteristics: A randomized clinical trial. Jama. 2013; 310(8):804-11.

40. Gane EJ, Stedman CA, Hyland RH, Ding X, Svarovskaia E, Symonds WT, et al. Nucleotide polymerase inhibitor sofosbuvir plus ribavirin for hepatitis C. The New England journal of medicine. 2013; 368(1):34-44.

41. Lai CL, Wong VW, Yuen MF, Yang JC, Knox SJ, Mo H, et al. Sofosbuvir plus ribavirin for the treatment of patients with chronic genotype 1 or 6 hepatitis $C$ virus infection in Hong Kong. Alimentary pharmacology \& therapeutics. 2016; 43(1):96-101.
42. Gower E, Estes C, Blach S, Razavi-Shearer K, Razavi $\mathrm{H}$. Global epidemiology and genotype distribution of the hepatitis C virus infection. J Hepatol. 2014; 61(1 Suppl):S45-57.

43. Lawitz E, Mangia A, Wyles D, Rodriguez-Torres M, Hassanein T, Gordon SC, etal. Sofosbuvir for previously untreated chronic hepatitis $\mathbf{C}$ infection. The New England journal of medicine. 2013; 368(20):1878-87.

44. Jacobson IM, Gordon SC, Kowdley KV, Yoshida EM, Rodriguez-Torres M, Sulkowski MS, et al. Sofosbuvir for hepatitis $\mathbf{C}$ genotype 2 or $\mathbf{3}$ in patients without treatment options. The New England journal of medicine. 2013; 368(20):1867-77.

45. Nelson DR, Cooper JN, Lalezari JP, Lawitz E, Pockros PJ, Gitlin N, et al. All-oral 12-week treatment with daclatasvir plus sofosbuvir in patients with hepatitis C virus genotype 3 infection: ALLY-3 phase III study. Hepatology (Baltimore, Md). 2015; 61(4):1127-35.

46. Foster GR, Pianko S, Brown A, Forton D, Nahass RG, George J, et al. Efficacy of sofosbuvir plus ribavirin with or without peginterferon-alfa in patients with hepatitis $\mathbf{C}$ virus genotype 3 infection and treatmentexperienced patients with cirrhosis and hepatitis C virus genotype 2 infection. Gastroenterology. 2015; 149(6):1462-70.

47. Mangia A, Piazzolla V. Overall efficacy and safety results of sofosbuvir-based therapies in Phase II and III studies. Digestive and Liver Disease. 2014; 46:S179-S85.

48. Farooqi JI HM, Chaudhry A, Sadik M, Din Z, Alam A, et al. Multi-center experience using Sofosbuvir \& Ribavirin with and without pegylated interferon to treathepatitis $\mathrm{C}$ patients with and without liver cirrhosis (RESiP Study: Real-life Experience with Sofosbuvir in Pakistan). Hepatology (Baltimore, Md). 2016; 64(S1):811-1050. 


\section{Truth, Like Surgery, May hurt, But it cures.}

\section{"Han Suyin"}

\begin{tabular}{|c|c|c|c|}
\hline \multicolumn{4}{|c|}{ AUTHORSHIP AND CONTRIBUTION DECLARATION } \\
\hline Sr. \# & Author(s) Full Name & Contribution to the paper & Author(s) Signature \\
\hline 1 & Sarmad Zahoor & Author & sirm d $\frac{2 \sqrt{100 L}}{a}$ \\
\hline 2 & Samreen Hameed & Co-Author & \\
\hline 3 & Saroosh Zahoor & Co-Author & \\
\hline 4 & Hafiz M. Sajid Jehangir & Co-Author & \\
\hline 5 & Samar Firdous & Co-Author & \\
\hline 6 & Salman Yousaf & Co-Author & \\
\hline 7 & Fariha Salman & Co-Author & Eilut \\
\hline
\end{tabular}

